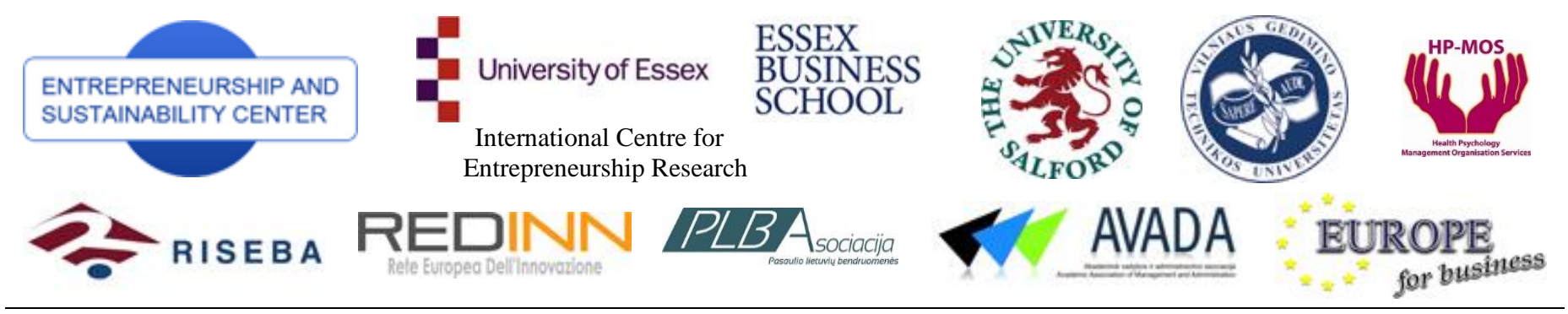

The International Journal

ENTREPRENEURSHIP AND SUSTAINABILITY ISSUES

ISSN 2345-0282 (online) http://jssidoi.org/jesi/aims-and-scope-of-research/

2015 Volume 2 Number 3 (March)

\title{
INSTITUTIONAL THEORY PERSPECTIVE AND INTERNATIONALIZATION OF FIRMS. HOW INSTITUTIONAL CONTEXT INFLUENCES INTERNATIONALIZATION OF SMES? ${ }^{1}$
}

\author{
Renata Korsakiené $\dot{e}^{1}$, Danuta Diskiené $\dot{e}^{2}$, Rasa Smaliukiené ${ }^{3}$ \\ ${ }^{1}$ Vilnius Gediminas Technical University, Faculty of Business Management, \\ Saulètekio al. 11, LT-10223 Vilnius, Lithuania \\ ${ }^{2}$ Vilnius University, Faculty of Economics, Universiteto g. 3, LT-01513 Vilnius, Lithuania \\ ${ }^{3}$ The General Jonas Žemaitis Military Academy of Lithuania \\ Šilo str. 5a., LT-10322, Vilnius, Lithuania
}

Emails: ${ }^{1}$ renata.korsakiene@vgtu.lt; ${ }^{2}$ danute.diskiene@ef.vu.lt; ${ }^{3}$ rasa.smaliukiene@mil.lt

Received 22 November 2014; accepted 12 January 2015

\begin{abstract}
Institutional context significantly impacts international behaviour of firms by facilitating or restricting internationalization processes. The application of institutional theory in business management field has led to the discussions how formal and informal constrains influence human behaviour and what relationships are observed between institutions and organisations. The authors of the paper aim to address the following questions: 1) how institutional theory perspective contributes to the explanation of firms' internationalization and 2) how institutional context impacts entry direction and speed of internationalization. The paper is based on comprehensive reviews of extant studies. The recommendations for future investigations are developed at the end of the paper.
\end{abstract}

Keywords: institutions, institutional theory, internationalization, SMEs, entry directions, entry speed

Reference to this paper should be made as follows: Korsakienè, R.; Diskienè, D.; Smaliukienè, R. 2015. Institutional theory perspective and internationalization of firms. How institutional context influences internationalization of SMES? Entrepreneurship and Sustainability Issues 2(3): 142-153.

DOI: http://dx.doi.org/10.9770/jesi.2014.2.3(3)

JEL Classifications: M10, M13, M19

\section{Introduction}

Small and medium size enterprises (SMEs) play an important role throughout all the European Union and contribute to economies by revenue generation and employment. Limitations of domestic markets and constant competition among firms encourage entrepreneurs seek opportunities abroad. Internationalization of firms is seen as a significant measure of competitive performance (Sousa et al. 2008) and contributes to economies of scale and scope, manufacturing efficiencies, access to foreign technological, marketing and management know-how (Korsakienė, Baranauskienė 2011; Korsakienė, Tvaronavičienė 2012; Korsakiené 2013; Korsakienè et al. 2014).

\footnotetext{
${ }^{1}$ This research was supported by a grant from the Research Council of Lithuania (project No. MIP-097/2014).
} 
Majority of governments have undertaken considerable efforts aiming to establish and develop favourable institutional infrastructure (Ketkar, Acs 2012). Institutional context significantly impacts international behaviour of firms by facilitating or restricting internationalization processes. Hence, regulatory, normative and culturalcognitive dimensions of institutions have attracted significant attention of researchers from various fields such as: sociology, economics, and political sciences. The authors of the paper aim to address the following questions: 1) how institutional theory perspective contributes to the explanation of firms' internationalization and 2) how institutional context impacts entry direction and speed of internationalization. Not going deep in prevailing discussions, the authors of the paper adopt the view that internationalization is the expansion of firm's operations to foreign markets.

The remainder of the paper is organized as follows. In section 1 the origins of institutional theory are investigated. In section 2 theoretical considerations of institutional theory in the context of multinational companies are discussed. In section 3 the role of institutional theory in the studies of SMEs is disclosed. The section 4 discusses the influence of institutional context on the directions of internationalization. The section 5 reveals how institutional context influence speed of internationalization. The final part concludes. The research is based on analysis and synthesis of scientific literature.

\section{The origins of institutional theory}

Institutional theory of organisations focuses on the central question why all organisations in the field tend to look and act the same (Miles 2012). Notably, institutional theory stems from sociology, economics and political sciences. The proponents of sociological perspective have investigated legitimacy role of institutions. They assert that organisations are impacted by different normative pressures, arising from external sources and within organisation. For instance, Zucker (1987) state that institutionalization of organisations reflected in theory shares two elements: 1) a rule-like, social fact quality of an organized pattern of action (exterior) and 2) an embedding in formal structures, such as formal aspects of organisations that are not tied to particular actors or situations (nonpersonal/objective). The normative pressures lead the organisations to be guided by legitimated elements and adoption of these elements increases the probability of survivor. Hence, Zucker (1987) has focused on three sources of institutionalization namely, the wider institutional environment, other organisations and internal organisational structure. Taking into consideration the view adopted by sociologists the conclusion can be drawn that institutional features of external environment of organisations influence both goals and means of actors. Hence, the role of institutional actors has attracted attention of researchers, namely: the state and professional bodies (Scott 1987). Later on the investigations have been extended focusing on regulatory, normative and cultural-cognitive dimensions of institutions (Scott 2008).

Meanwhile, the attitudes towards institutional theory from economics share the idea that institutions are the rules of the game in a society (North 1990). Notably, the proponents of economics perspective distinguished two groups of institutions: formal constraints (e.g. laws, rules, constitutions) and informal constraints (e.g. norms of behaviour, conventions, and self-imposed codes of conduct). The set of macro-level institutions influence transaction costs. Moreover, some scholars point out that the interaction of institutions and organisations shapes "the institutional evolution of an economy" (North 1994). The contributions of institutions to uncertainty diminishment in the society by a stable structure for human interaction and the role of institutions in economic performance have been investigated by different scholars. These investigations conclude that, governance structures are seen as the most critical driving force.

The scholars, representing political science, aimed to answer the question: how do institutions affect the behaviour of individuals? The investigations adopted the views similar to sociological and economics perspectives. However, the main concern of researchers is related to actions of individuals affecting political outcomes (Hall, Taylor 1996). Notably, the different streams of researches have been emerging. On the other hand, all studies aimed to answer seminal questions: how do actors behave, what do institutions do and why do institutions persist over time? Institutional theory has been applied by different researchers working in business management field what has led to a wider adoption of sociological and economics perspectives. According to Peng and Heath (1996), sociological and economics perspectives toward institutional theory share similar beliefs and complement each other. The 
scholars agree that institutional pressures can be divided into two broad groups of institutions, namely stemming from the macro-social environment and inter-organisational relationships. Hence, institutional researchers investigated external institutions such as rules, regulatory structures and agencies. Later on the field has been extended to include other firms in the same industry or units within the same firm (Hessels, Terjesen 2010). Summarized different views of institutional theory are presented in Table 1.

Table 1. The comparison of different branches of institutional theory

\begin{tabular}{|l|l|l|}
\hline \multicolumn{1}{|c|}{ Characteristics } & \multicolumn{1}{|c|}{ Economic/political branch } & \multicolumn{2}{|c|}{ Sociology/organisation theory branch } \\
\hline Assumptions & $\begin{array}{l}\text { People make decisions based on the } \\
\text { convenience and standardization of rules } \\
\text { and agreements }\end{array}$ & $\begin{array}{l}\text { People make decisions based on } \\
\text { heuristics because of cognitive } \\
\text { limitations and take action based on } \\
\text { conventions and preconscious behaviour }\end{array}$ \\
\hline Drivers of human behaviours & Rules and procedures, formal control & $\begin{array}{l}\text { Social norms, shared cultures, cognitive } \\
\text { scripts, and schemas }\end{array}$ \\
\hline $\begin{array}{l}\text { Relationship between institutions and } \\
\text { organisations }\end{array}$ & $\begin{array}{l}\text { External institutions create structures for } \\
\text { organisations }\end{array}$ & $\begin{array}{l}\text { Organisations adjust and conform to } \\
\text { values and limits prescribed by a } \\
\text { society's institutions }\end{array}$ \\
\hline
\end{tabular}

Source: Bruton et al. (2010)

Scientific investigations in business management field suggested different definitions of institutions. Not going deep into elaborated discussion, the authors of the paper adopt the approach proposed by Lawrence et al. (2002) stating that institutions are widely diffused practices, technologies or rules that have become entrenched in the same that it is costly to choose other practices, technologies or rules.

\section{Institutional theory and MNCs}

The assumptions of institutional theory have been extended by scholars focused on multinational corporations (MNCs) and aiming to investigate a wide array of issues and theorize at multiple levels of analysis. The nature of MNCs leads to diverse external environment and complex internal environment. For instance, externally MNCs are exposed to different institutional, cultural and economic environments. The fact that MNCs are facing issues related with establishment and maintenance of legitimacy in multiple host environments was acknowledged by scholars (Kostova, Zaheer 1999). Meanwhile, internally MNCs are comprised of different units operating in different external environments. The investigations carried out by Roth and Kostova (2003) confirm heterogeneity and complexity of the MNCs context being applied for both empirical and conceptual purposes. Hence, numerous streams of researches aiming to disclose different issues of MNCs have been emerging.

To date, studies of MNCs applying institutional theory can be grouped into the following groups: 1) studies focused on institutional profile/institutional distance, 2) studies focused on institutional change/transition economies, 3) studies focused on national institutional systems, 4) studies focused on institutional constrains of MNCs, 5) studies focused on diffusion, adoption and institutionalization of organisational practices across units within MNCs and across national boundaries and 6) studies focused on MNCs and host country institutional environment (Kostova et al. 2008). The scholars have been led by idea that the survival of organisation depends on the alignment with institutional environment and ability to comply with institutional pressures. The concepts of organisational field, legitimacy, isomorphism and mechanisms of institutional pressures have been the most cited in international management literature. However, some critics appear in scientific literature regarding too narrow view of institutional theory adopted by different researchers (Kostova et al. 2008). Hence, a blended institutional perspective comprising concepts of social embeddedness of organisations, the ideas of agency, social construction, power and politics have been proposed.

\section{The role of institutional theory in the studies of SMEs}

The activities of entrepreneurs are constrained and fostered by institutions (Bruton et al. 2010). For instance, entrepreneurial opportunities are limited by institutional environment impacting the size and rate of new firms. 
Meanwhile, availability of capital and favourable market incentives foster entrepreneurial activities. Hence, institutional theory has gained popularity among scholars concerned with entrepreneurship issues. Bruton et al. (2010) observed that application of institutional theory in entrepreneurship field has been growing since 1999. The scholars acknowledge that the main contribution of neo-institutional field of research has been in the focus on the spread of various organisational practices, models and governance mechanisms. Hence, the application of institutional theory has led to three major streams of investigations: institutional setting, legitimacy and institutional entrepreneurship.

Notably, inadequate institutional environment is common for developing countries, while developed countries have more established institutional framework. The research questions have been raised how and why levels of entrepreneurship vary by country. Hence, majority of studies aimed to explain how an emerging economy entrepreneurship phenomenon differs from a mature economy (Bruton et al. 2008) and let the scholars to define factors hindering establishment and development of new ventures. Building on the concepts developed by institutional theory, the scholars discussed regulatory, normative and cognitive dimensions in emerging economies of China (Peng 2003), Eastern Europe (Manolova et al. 2008) and Russia (Aidis et al. 2008).

Macro-level institutional constraints widely investigated were: barriers to entry to market, export and import barriers, trade and investment policies. With respect to regulatory dimension of developing countries, referring to formal lows and regulations, the absence of effective market based institutions able to protect property rights, fair competition and financial discipline was observed (Manolova et al. 2008). The analysis of various studies led to the fact that ineffective formal regulatory institutions encourage entrepreneurs rely more on informal norms and seek to design alternative governance structures. Hence, normative dimension of institutions, comprising professional societies that determine roles and expectations for certain groups, play an important role, especially in developing countries. Finally, cultural-cognitive dimension of institutions, referring to accepted beliefs and values shared among individuals through social interaction, which guide behaviour, has to be taken into consideration. While scientific investigations focused on different countries identified norms facilitating and promoting entrepreneurship, some scholars observed negative societal attitudes underpinned by a distinct institutional legacy, hindering entrepreneurial rates and initiatives (Manolova et al. 2008).

Weak regulatory institutions lead to the higher corruption level of developing countries what might discourage to start business. Moreover, some scholars claim that formal institutions interact with informal institutions by complementing or substituting each other (North 1990). Complementarity is observed when informal institutions strengthen incentives to comply with formal rules. Meanwhile, substitution appears when informal institutions structure incentives of individuals, incompatible with formal laws. These assumptions led to the conclusions that both formal and informal institutions impact decisions of business people (Tonoyan et al. 2010). Hence, the need to develop more favourable social environment of developing countries is emphasized.

Recent works identified that the gap between what some large groups of society believe to be legal and what consider being legitimate exists (Webb et al. 2009). The term "legal" refers to the rules defined by laws and regulations, while "legitimacy" refers to the rules specified by norms, values and beliefs. Hence, informal economies falling within informal institutional boundaries but outside formal institutional boundaries have been distinguished. These economies create opportunities for entrepreneurs that are illegal but legitimate for some groups of society and let to take advantage. Notably, informal economies might be identified in both developed and developing economies.

Bruton et al. (2010) assert that institutional environment determines the process of gaining cognitive and moral legitimacy thus increasing survivor of SMEs. Notably, legitimation of activities is seen as the important factor aiming to secure resources and gaining support from key stakeholders. Hence, some firms are concerned with strategies letting to gain approval of certain activities from both political and general public perspective. Some scholars note, that obtaining of legitimacy for a new firm or business model in developing economies is especially complicated (Ahlstrom et al. 2008). Therefore, some activities of firms, such as image building, networking and developing close connections with government, appear to be the most crucial. Referring to the works of 
institutional theorists, the scholars outline organisational procedures, structures and personnel used in legitimation processes.

Finally, different actors aiming to encourage particular institutional arrangement have been emerging. Hence, institutional entrepreneurship has been developing as a new phenomenon in scientific literature. The main concerns of scholars have become why and under what circumstances firms are prompted to change institutionalized contexts (Greenwood, Suddaby 2006) and what challenges institutional entrepreneurs are facing (Battilana et al. 2009).

\section{Institutions and SMEs internationalization: entry direction}

Internationalization of firms is seen as an important measure of competitive performance at national as well as at regional level (Sousa et al. 2008). The scholars adopted the idea that internationalization of new ventures is seen as rather complex phenomena and requires integration of several perspectives. In comparison to MNCs, new firms lack resources and are faced with low level of legitimacy. While large companies are better equipped to deal with internationalization issues, small firms benefit more with advancing institutional mechanisms (Ketkar, Acs 2012). Hence, the insights adopted from studies focused on MNCs do not let us explain why SMEs internationalize. On the other hand, some scholars assert that majority of studies focused on SMEs internationalization ignore the role of external environment (e.g. home market, organisational field) (Hessels, Terjesen 2007). Hence, the investigations of various factors stemming from institutional context and contributing to internationalization of SMEs have to be discussed.

One stream of researches was focused on the link between institutional theory, entry mode choice and direction of SMEs. Hessels and Terjesen (2007) argue that factors relating to the perceptions of the home market environment are relevant in explaining SME export behaviour and export mode. The assumptions have been developed taking into consideration resource-dependence and institutional theories. Institutional theory let to suggest that the greater the pull from the global organisation field, the more likely the firm will export oversees. For instance, the investigation of Dutch SMEs led to the conclusion that institutional theory perspectives explain the decision to export, while resource dependency arguments guide the choice between direct and indirect export modes (Hessels, Terjesen 2007).

Meanwhile, the notion, that existing findings on the influence of institutions on entry mode choice are largely inconclusive prevails (Schwens et al. 2011). The scholars assert that the institutional context doesn't influence entry mode choice independently and institutional environment has to be analysed with other decision-making criteria investigated in scientific literature. Schwens et al. (2011) adopted interpretation of institutional theory as follows: socially constructed beliefs and role systems exert strong influence over organisations' structure and conduct, including internationalization. The interpretation led to the investigation of informal institutional distance and formal risk determined by institutional context. Notably, informal institutional distance is defined as the cultural and ideological differences between firm's home and host country. Meanwhile, institutional context determines formal risk, which is defined as the constraints resulting from insufficiently developed market support institutions in the host country. Putting emphasis on informal institutional distance and formal institutional risk of host country, Schwens et al. (2011) investigated German SMEs and found that the influence of international experience, proprietary know-how and strategic importance on SME mode choice is contingent on the institutional context of the host country.

Building on the strategy literature Yamakawa, Peng and Deeds (2008) have proposed integration of industry-based view, resource-based view and institution-based view (Figure 1). Industry-based view emphasizes the impact of industry's conditions on internationalization decisions. Resource-based view highlights firm-specific resources and capabilities impacting performance of firms. Finally, institution-based view put emphasis on formal and informal institutions impacting performance of firms. The idea that industries with high degree of competition and technology intensiveness influence internationalization of firms has been proposed. Considering resource-based view, the firms focus on learning, aim to establish alliances and leverage social capital and entrepreneurial 
orientation. Finally, regulative, normative and cognitive forces both at home and abroad impact internationalization.

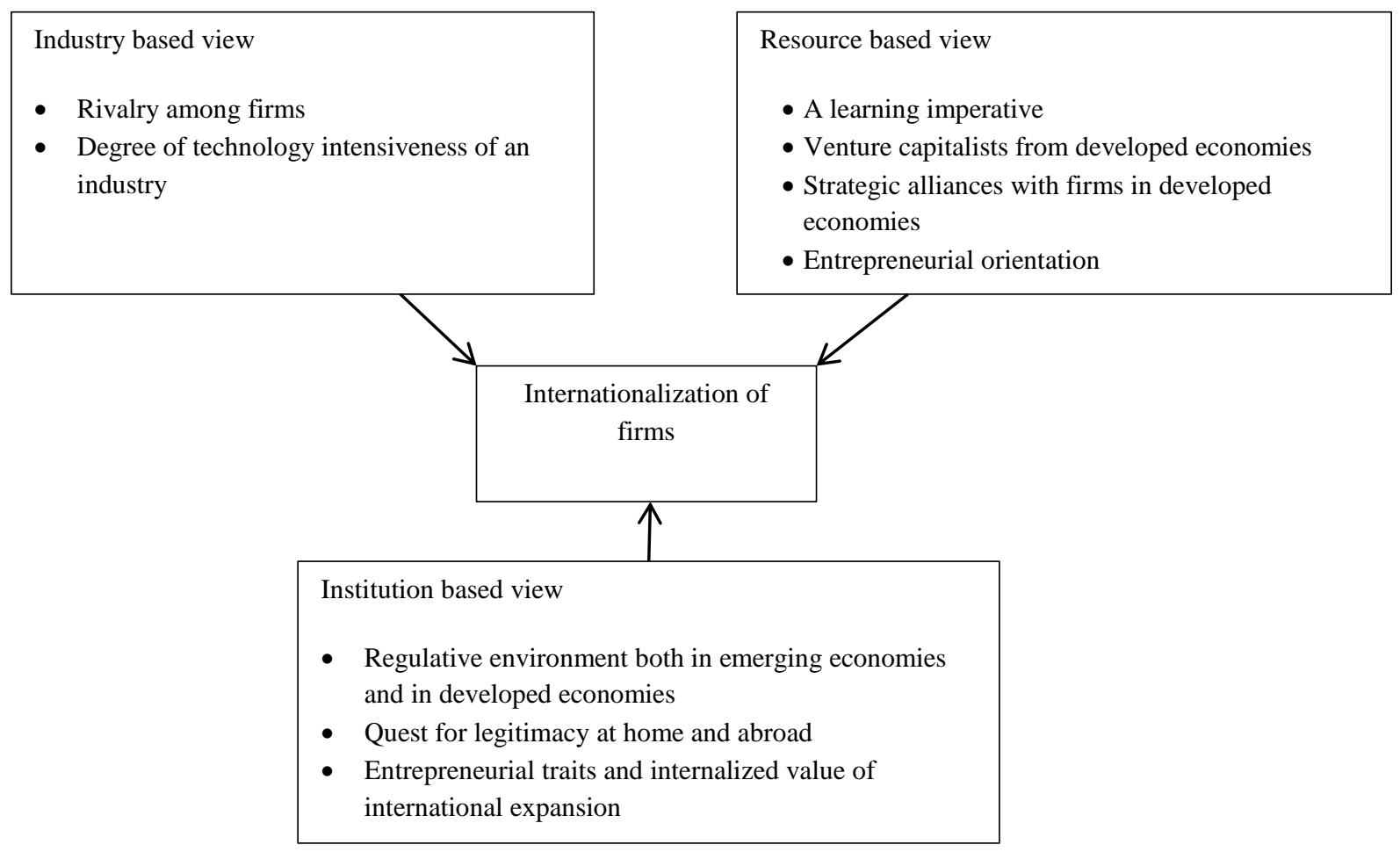

Fig.1. Three perspectives

Source: Yamakawa et al. 2008

Yamakawa et al. (2008) were concerned with directions of SMEs internationalization. Specifically, the interest was focused on SMEs based in emerging economies and moving to developed economies. Industry-based view led to the conclusion that internationalization of SMEs from emerging economies to developed economies is beneficial due to 1) enhanced learning opportunities, 2) lower level of institutional and country risk and 3) greater market potential (Yamakawa et al. 2008). On the other hand, new ventures are motivated to internationalize by a high degree of competition in a domestic industry. The explanation resides in the fact that developed economies are related to lower competitive, expropriation and corruption risk than emerging economies. Ultimately, firms aim to replicate each other's strategic decisions under competitive pressure. Notably, the level of technological intensity is seen as a key driving force fostering new firms to expand abroad. Firms from high technology industries are forced to move on bigger markets aiming to justify investments on products or services. Meanwhile, firms from low technology industries may have little incentive to internationalize via foreign direct investments.

The adoption of resource-based view led to the explanation of the main internationalization benefits, namely: 1) organizational learning via foreign direct investments, 2) overcoming resource and capabilities deficiencies and 3) leveraging entrepreneurial orientation (Yamakawa et al. 2008). Firms moving from emerging economies to developed economies put emphasis on "exploration" of new opportunities rather on "exploitation" of existing advantage. In addition, resource and capabilities deficiencies might be overcome by venture capital and strategic alliances. Notably, venture capital firms facilitate investments of SMEs in developed economies. Meanwhile, strategic alliances let firms to lower risk of internationalization. Scholars argue that internationalization is a certain act of entrepreneurship (Zahra et al. 2000). Hence, a high level of entrepreneurial orientation defined by autonomy, innovativeness, risk-taking, aggressiveness and proactiveness motivates international expansion of SMEs. Regulatory environment of some emerging economies (e.g. China and Vietnam) could be described as discriminating new ventures (Yamakawa et al. 2008). Hence, "push" factors such as harsh regulation and "pull" factors such as more friendly institutional environment let us explain SMEs internationalization, aiming to overcome financial barriers established in home countries. On the other hand, the differences in regulatory regimes 
can determine the lack (or extent) of institutional support for international activities (Kiss, Danis 2008). Hence, we can predict that countries with high level of institutional development provide higher support, while countries with low level of institutional development provide lower support. The explanation resides in well-developed banking systems, strong public equity markets and established venture capital industries, distinguishing developed and developing countries. Notably, internationalization from emerging economies to developed economies let firms to establish legitimacy in their home markets. Home country governments, investors and consumers get appropriate signals, what lead to the fact that internationalized firms receive higher recognition from government than non-internationalized firms (Yamakawa et al. 2008). Meanwhile, other scholars assert that normative dimension determines the extent to which entrepreneurs value international activities. Hence, the proposition that less developed countries lack international experience and thus strong normative values supporting internationalization has been suggested (Kiss, Danis 2008). Above provided discussion let us compare main drivers of internationalization as well as the role of institutions. Notably, two groups of firms are distinguished: 1) expanding from emerging to developed countries and 2) expanding from developed to emerging countries. On the contrary to the firms from emerging markets, we can predict that SMEs from developed countries are richer in resources and capabilities and are supported by institutional context at home country (Table 2). Meanwhile, SMEs from emerging markets are more vulnerable due to weaker institutional support. Thus, relationships between institutions and SMEs are different what lead to different drivers of internationalization.

Table 2. Main drivers of internationalization of SMEs and role of institutions

\begin{tabular}{|l|l|l|}
\hline & \multicolumn{1}{|c|}{$\begin{array}{c}\text { Internationalization from emerging to developed } \\
\text { countries }\end{array}$} & \multicolumn{1}{c|}{$\begin{array}{c}\text { Internationalization from developed to emerging } \\
\text { countries }\end{array}$} \\
\hline Drivers & $\begin{array}{l}\text { Learning opportunities, lower level of institutional } \\
\text { and country risk, greater market potential, the aim to } \\
\text { overcome resource and capabilities deficiencies, } \\
\text { leveraging entrepreneurial orientation }\end{array}$ & $\begin{array}{l}\text { Cheaper production opportunities, possibility to } \\
\text { expand sales for products or services, to realize } \\
\text { additional production capacity, to avoid strict } \\
\text { regulation in home country }\end{array}$ \\
\hline $\begin{array}{l}\text { Relationship } \\
\text { between } \\
\text { institutions and } \\
\text { SMEs }\end{array}$ & $\begin{array}{l}\text { SMEs are seeking to compensate weakness of } \\
\text { institutional environment in emerging countries } \\
\text { (e.g. in terms of capital, labor and product markets) } \\
\text { and increase their legitimacy in home country. }\end{array}$ & $\begin{array}{l}\text { SMEs are aiming to exploit support of institutional } \\
\text { environment in developed countries (e.g. well- } \\
\text { developed banking systems, strong public equity } \\
\text { markets and established venture capital industries), } \\
\text { stronger values supporting internationalization }\end{array}$ \\
\hline
\end{tabular}

Source: developed by authors (considering Kiss and Danis 2008; Yamakawa et al. 2008)

Finally, the notion that SMEs internationalization is the outcome of its internal abilities and leader's cognition of its external environment has been proposed recently (Cheng, Yu 2008). Yanakawa, Peng and Deeds (2008) assume that internationalization of new ventures is fostered by the distinctive cognitions of entrepreneurs, aiming to contribute to the nation's success and to do right things despite the risk. On the other hand, low development level of institutions increases the role of a social network and determines the path by which internationalization is implemented (Kiss, Danis 2008). Meanwhile, Cheng and Yu (2008) argue that the decision to go abroad may have more to do with sociological factors than economic factors. The explanation of internationalization decisions resides in institutional pressures. According to proponents of institutional theory organisational behaviours originate in the context of institutional environments and organisations have to conform to this context. Hence, the role of institutions in internationalization processes of new ventures has been analysed taking into consideration regulative, normative and cognitive pillars proposed by Scott (2008). The researchers assert that actions of entrepreneurs, adopting international strategy, are facilitated and constrained by ongoing process of institutional relations in both home and host countries (Yeung 2002).

\section{Institutions and SMEs internationalization: speed of internationalization}

The literature focused on SMEs internationalization investigates when new ventures start international activities. Speed of internationalization refers to the time from the company's foundation to its first entry into international markets (Cieslik, Kaciak 2009). However, some scholars point out that "explanation of conditions under which the speed of international expansion increases or decreases" is seen as inconsistent (Luo et al. 2005: 705) and scarce (Mohr, Batsakis 2014). Notably, the speed with which firms expand internationally is seen as important 
facet of internationalization. For instance, the Born Globals or International New Ventures (INV) attracted significant attention of researchers due to fast internationalization process. These firms are defined as entrepreneurial and internationalize from the outset. While literature aimed to investigate high-tech firms (Crick 2009; Musteen et al. 2010), the investigations related to traditional firms that may have operated domestically for long period were limited (Mohr, Batsakis 2014).

On the other hand, the literature focused on the speed of internationalization is vast and lacks common agreements. Some scholars defined INV as being involved in international markets at or immediately after establishment (Acedo, Jones 2007). Hence, the discussions related to the speed of internationalization range from instant internationalization to gradual internationalization considering business development. Notably, majority of studies refer to speed as "the time it takes to internationalize from inception of firm" (Chetty et al. 2014: 633). Acedo and Jones (2007: 237) state that in some definitions "speed of internationalization is accompanied by a specified level of export ratios and a range of measures from $20 \%$ of total turnover in 2 years to around $80 \%$ within 6 years have been advanced". Considering different speed of internationalization, the study distinguished non-exporters, exporters that took more than 5 years to become international and firms that took less than 5 years to become international since foundation. Comprehensive study carried out by Chetty et al. 2014 distinguished main reasons impacting speed, namely: characteristics of entrepreneur and management, network of relationships and ties, institutions and technology in foreign markets and firm strategy.

Notably, the investigations carried out by Coeurderoy and Murray (2008) led to the conclusion that the timing of early internationalization depends on corporate resources, organisational experience and sector effect. On the other hand, regulatory environment determines internationalization dynamics of newly established technology firms. Meanwhile, Kiss and Danis (2008) examined the relationships between specific ties of entrepreneurs and internationalization speed and how these relationships depend on institutional context of country. Thus, the scholars argued that stronger ties were the most important in the context of low institutional development and vice versa. Hence, the authors of the paper agree with other scholars indicating that speed of internationalization is endogenous variable impacted by micro- and macro-level (host country) conditions (Luo et al. 2005). Hence, the conclusion can be drawn that the speed of internationalization is not isolated from firm's capabilities. Some micro level factors such as: ability to enter, operate, compete and sustain in international market have to be taken into consideration (Luo et al. 2005). Hence, the emphasis has to be put on international experience, innovative capability, marketing capability and location. On the other hand, we argue that institutional context either diminish or increase speed of internationalization. Hence, macro level factors such as host country's institutional and technological infrastructures have to be investigated.

Finally, the differences among the firms as well as industries play a significant role in predicting the speed of internationalization. The study carried out by Luo et al. (2005) shed some light on the difference between traditional companies and non-traditional (e.g. e-commerce) companies. While cultural difference influences internationalization speed, cultural distance doesn't have significant impact on the speed of internationalization of non-traditional companies. Hence, the conclusion can be drawn that traditional and non-traditional firms are following different paths of internationalization. Meanwhile, physical infrastructure (e.g. technology supportiveness and internet use) as well as regulatory infrastructure (e.g. legal protection and government transparency) were considered the most significant variables impacting the rate of internationalization.

Table 3. Main variables of internationalization speed and role of institutions

\begin{tabular}{|c|c|c|}
\hline & Traditional SMEs & Non-tradition SMEs \\
\hline $\begin{array}{l}\text { Speed of } \\
\text { internationalization }\end{array}$ & $\begin{array}{l}\text { Internationalize later on in life cycle of the firm and } \\
\text { at the lower speed }\end{array}$ & $\begin{array}{l}\text { Internationalize after the inception and at the high } \\
\text { speed }\end{array}$ \\
\hline $\begin{array}{l}\text { Relationship between } \\
\text { institutions and } \\
\text { SMEs }\end{array}$ & $\begin{array}{l}\text { All factors of institutional context (e.g. cultural, } \\
\text { legal technological) were considered equally } \\
\text { significant variables impacting the rate of } \\
\text { internationalization. }\end{array}$ & $\begin{array}{l}\text { Physical infrastructure (e.g. technology } \\
\text { supportiveness and internet use) and regulatory } \\
\text { infrastructure (e.g. legal protection and government } \\
\text { transparency) were considered the most significant } \\
\text { variables impacting the rate of internationalization }\end{array}$ \\
\hline
\end{tabular}

Source: developed by authors (considering Luo et al. 2005; Kiss and Danis 2008) 
The above discussion let us conclude that traditional and non-traditional SMEs are impacted by both industry and institutional contexts (Table 3). However, the most significant variables for non-traditional SMEs are seen physical infrastructure and regulatory infrastructure of host country. Meanwhile, traditional SMEs are impacted by all variables stemming from institutional context. Hence, contrary to non-traditional SMEs, traditional SMEs are influenced by informal institutional distance, defined by the cultural and ideological differences between home and host countries.

\section{Conclusions}

The origins and development of institutional theory are traced in economics, sociology and political sciences. However, the ever growing popularity of institutional theory among proponents of business management field is observed as well. The application of institutional theory in business management field has led to the discussions how formal and informal constrains influence human behaviour and what relationships are observed between institutions and organisations.

The assumptions of institutional theory have been extended on MNCs defined by diverse external environment and complex internal environment. The alignment of organization with institutional context and ability to comply with institutional pressures are seen of the highest significance. These considerations have led to the different streams of scientific investigations and wide array of issues. Further, institutional theory has gained recognition among the scholars focusing on entrepreneurship issues and has led to three major streams of investigations: institutional setting, legitimacy and institutional entrepreneurship.

Institutional context defines limitations for SMEs aiming to expand both nationally and internationally. Increased globalization and liberalization of markets have led to more intense competition what requires SMEs to match international competitors. On the other hand, the growth of SMEs is related to internationalization processes due to the obvious limitations of home markets. Small size of firms and limited resources are seen as considerable disadvantage of firms which can be overcome by more favorable institutional context. However, the difference is observed between SMEs from developed and emerging markets.

Emerging markets are characterized by diverse institutional environment in comparison to developed economies. These differences lead to different institutional support and consequently different drivers and aspirations for internationalization. Hence, institutional context influence entry mode choice and direction of SMEs. Finally, institutional context might increase or limit the speed of internationalization. Traditional and non-traditional firms are following different paths of internationalization. Hence, physical infrastructure and regulatory infrastructure were considered the most significant variables impacting the rate of internationalization of non-traditional SMEs.

Considering research approach adopted in the paper, additional empirical research is needed to disclose the influence of institutional context on the internationalization of SMEs. Specifically, the focus has to be concentrated on emerging countries, experiencing constant institutional transformations. These transformations change entrepreneurial behavior and contribute to internationalization of SMEs. Of particular benefit, would be expanding the research to traditional and non-traditional enterprises aiming to disclose different patterns of internationalization impacted by a set of factors from home and host countries institutional environment. These investigations will help to uncover weather it is appropriate to make generalizations regarding traditional and nontraditional firms. Traditional SMEs that may have operated domestically for long period before internationalization have to be investigated more consistently. Considerations have to be given to integration of several perspectives contributing to the understanding of complex phenomena of internationalization.

The research contributes to the theory by portraying through a review of extant studies how development of institutional theory perspective contributed to the explanation of firms' internationalization. In addition, the paper focuses on directions and speed of SMEs internationalization, which thus represent challenges for managers. 


\section{References}

Acedo, F.J.; Jones, M.V. 2007. Speed of internationalization and entrepreneurial cognition: Insights and a comparison between international new ventures, exporters and domestic firms, Journal of World Business 42(3): 236-252.

Ahlstrom, D.; Bruton, G.D.; Yeh, K.S. 2008. Private firms in China: building legitimacy in an emerging economy, Journal of World Business 43: 385-399.

Aidis, R.; Estrin, S.; Mickiewicz, T. 2008. Institutions and entrepreneurship development in Russia: a comparative perspective, Journal of Business Venturing 23: 656-672.

Batillana, J.; Leca, B.; Boxenbaum, E. 2009. How actors change institutions: towards a theory of institutional entrepreneurship, The Academy of Management Annals 3(1): 65-107.

Bruton, G.D.; Ahlstrom, D.; Obloj, K. 2008. Entrepreneurship in emerging economies: where are we today and where should the research go in the future, Entrepreneurship Theory and Practice 32(1):1-14.

Bruton, G.D.; Ahlstrom, D.; Li, H.-L. 2010. Institutional theory and entrepreneurship: where are we now and where do we need to move in the future, Entrepreneurship Theory and Practice 34(3): 421-440.

Cheng, H. - L.; Yu, C.- M.J. 2008. Institutional pressures and initiation of internationalization: Evidence from Taiwanese small- and medium-sized enterprises, International Business Review 17: 331-348.

Chetty, S.; Johanson, M.; Martín, O.M. 2014. Speed of internationalization: Conceptualization, measurement and validation, Journal of World Business 49(4): 633-650.

Cieslik, J.; Kaciak, E. 2009. The speed of internationalization of entrepreneurial start-ups in a transition environment, Journal of Developmental Entrepreneurship 14(4): 375-392.

Coeurderoy, R.; Murray, G. 2008. Regulatory environments and the location decision: evidence from the early foreign market entries of new-technology-based firms, Journal of International Business Studies 39(4): 670-687.

Crick, D. 2009. The internationalization of born global and international new venture SMEs, International Marketing Review 26(4/5): 453476.

Greenwood, R.; Suddaby, R. 2006. Institutional entrepreneurship in mature fields: the big five accounting firms, Academy of Management Journal 49(1): 27-48.

Hall, P.A.; Taylor, R.C.R. 1996. Political science and the three new institutionalism. MPIFG Discussion Paper 96/6.

Hessels, J.; Terjesen, S. 2010. Resource dependency and institutional theory perspectives on direct and indirect export choices, Small Business Economics 34: 203-220.

Hessels, J.; Terjesen, S. 2007. Resource dependency and institutional theory perspectives on direct and indirect export choices, Small Business Economics 34(2): 203-220.

Ketkar, S.; Acs, Z.J. 2012. Cultural burdens and institutional blessings: internationalization by SMEs from emerging countries. GMU School of Public Policy Research Paper, March.

Kiss, A.N.; Danis, W.M. 2008. Country institutional context, social networks and new venture internationalization speed, European Management Journal 26: 388-399.

Korsakienè, R., Baranauskienè, A. 2011. Factors impacting sustainable internationalization: a case of multinational company, Journal of Security and Sustainability Issues 1(1): 53-62. DOI: http://dx.doi.org/10.9770/jssi.2011.1.1(5)

Korsakienė, R., Tvaronavičienė M. 2012. The Internationalization of SMEs: an integrative approach, Journal of Business Economics and Management 13(2): 294-307.

Korsakienè, R. 2013. Internationalization of construction firms: what strategy do they follow?, Entrepreneurship and Sustainability Issues 1(2): 99-106. DOI: http://dx.doi.org/10.9770/jesi.2013.1.2(4)

Korsakienè, R.; Diskienè, D.; Drūteikienè, G. 2014. The role of human capital and organizational learning in internationalization of SMEs. The 8th international scientific conference Business and Management 2014: selected papers. May 15-16, 2014. Vilnius: Technika, ISSN 2029-4441. ISBN 9786094576522. p. 76-84. 
Kostova, T.; Zaheer, S. 1999. Organizational legitimacy under conditions of complexity: the case of the multinational enterprise, Academy of Management Review 24(1): 64-81.

Kostova, T.; Roth, K.; DAcin, M.T. 2008. Institutional theory in the study of multinational corporations: a critique and new directions, Academy of Management Review 33(4): 994-1006.

Lawrence, T.B.; Hardy, C.; Phillips, N. 2002. Institutional effects of interorganizational collaboration: the emergence of proto-institutions, Academy of Management Journal 45(1): 281-290.

Luo, Y.D.; Zhao, J.H.X.; Du, J.J. 2005. The internationalization speed of e-commerce companies: an empirical analysis, International Marketing Review 22(6): 693-709.

Manolova, T.S.; Eunni, R.V.; Gyoshev, B.S. 2008. Institutional environments for entrepreneurship: evidence from emerging economies in Eastern Europe, Entrepreneurship Theory and Practice 32(1): 203-218.

Miles, J.A. 2012. Management and Organisation Theory. John Wiley\&Sons Inc.

Mohr, A.; Batsakis, G. 2014. Intangible assets, international experience and the internationalisation speed of retailers, International Marketing Review 31(6): 601-620.

Musteen, M.; Francis, J.; Datta, D. 2010. The influence of international networks on internationalization speed and performance: a study of Czech SMEs, Journal of World Business 45(3):197.

North, D.C. 1990. Institutions, Institutional Change and Economic Performance. Cambridge University Press.

North, D.C. 1994. Economic performance through time, American Economic Review 84(3): 359-368.

Peng, M.W.; Heath, P.S. 1996. The growth of the firm in planned economies in transition: institutions, organizations, and strategic choice, Academy of Management Review 21(2): 492-528.

Peng, M.W. 2003. Institutional transitions and strategic choices, Academy of Management Review 28(2): 275-296.

Roth, K.; Kostova, T. 2003. The use of multinational corporation as a research context, Journal of Management 29(6): 883-902.

Scott, W.R. 2008. Institutions and Organizations: Ideas and Interests. 3rd Ed. Los Angeles: Sage.

Scott, W.R. 1987. The adolescence of institutional theory, Administrative Science Quarterly 32(4): 493-511.

Schwens, C.; Eiche, J.; Kabst, R. 2011. The moderating impact of informal institutional distance and formal institutional risk on SME entry mode choice, Journal of Management Studies 48(2): 330-351.

Sousa, C. M. P., Martinez-Lopez, F. J., Coelho, F. 2008. The determinants of export performance: a review of the research in the literature between 1998 and 2005, International Journal of Management Reviews 10(4): 343-374.

Tonoyan, V.; Strohmeyer, R.; Habib, M.; Perlitz,M. 2010. Corruption and entrepreneurship: how formal and informal institutions shape small firm behavior in transition and mature market economies, Entrepreneurship Theory and Practice 1:803-832.

Webb, J.W.; Tihanyi, L.; Ireland, R.D.; Sirmon, D.G. 2009. You say illegal, I say legitimate: entrepreneurship in the formal economy, Academy of Management Review 34(3): 492-510.

Yamakawa, Y.; Peng, M.W.; Deeds, D.L. 2008. What drives new ventures to internationalize from emerging to developed economies? Entrepreneurship: Theory \& Practice 32(1): 59-82.

Yeung, H.W.-C. 2002. Entrepreneurship in international business: an institutional perspective, Asia Pacific Journal of Management 19: 2961.

Zahra, S.; Ireland, R.; Hitt, N. 2000. International expansion by new venture firms: international diversity, mode of market entry, technological learning, and performance, Academy of Management Journal 43: 925-950.

Zucker, L.G. 1987. Institutional theories of organization, Annual Review of Sociology 13: 443-464. 
Renata KORSAKIENE - PhD, works as Associate Professor at the Department of Economics and Management of Enterprises, Vilnius Gediminas Technical University. She authored and co-authored more than 70 scientific papers, published in scientific journals and conference proceedings. Her research interests involve: strategic management, internationalisation and international entrepreneurship, entrepreneurship and human capital.

Danuta DISKIENE - Doctor of social sciences (HP), works as Professor at the Department of Management, Faculty of Economics, Vilnius University. She authored and co-authored more than 60 scientific publications and two mographs. She participated in national and international projects. Her research interests involve: management, leadership, intercultural management, managerial behavior in different cultures.

Rasa SMALIUKIENE் - PhD, works as Professor at Vilnius Gediminas Technical University and General Jonas Zemaitis Lithuanian Military Academy (Lithuania). Research interests: entrepreneurship, social responsibility, leadership.

This is an open access journal and all published articles are licensed under a Creative Commons Attribution 4.0 International License 